\title{
HOUSING MORTGAGE IN THE RUSSIAN FEDERATION IN H1 2013
}

\author{
G.Zadonsky
}

In Q2 2013, the monthly weighted average interest rate on ruble-denominated housing mortgage loans was no longer on the rise, after a more than year-long period of growth: the interest rate for June was $12.6 \%$ against its record high of 12.9\% in March 2013. The volume of housing mortgage lending in Q2 2013 amounted to $R b 315.5 \mathrm{bn}$, which is by $26.63 \%$ higher than the volume of similar loans granted over Q2 2012. The share of outstanding ruble-denominated debt against housing mortgage credits relative to the sum of residual debt continues to be on the decline (1.24\% as of $1 \mathrm{July} 2013$ against 1.41\% as of 1 April 2013.); the same is true with regard to the corresponding share of outstanding debt denominated in foreign currencies (12.45\% as of $1 \mathrm{July} 2013$ against $11.78 \%$ as of 1 April 2013.). The share of debt against defaulted housing mortgage credits (HMC) (with payments overdue for periods over 180 days) in the sum of total debt denominated in all currencies shrank to 1.15\%.

Over first half year of 2013, according to data published by the RF Central Bank (CB), credit institutions issued a total of 357,311 housing credits $(\mathrm{HC})$ in the amount of $\mathrm{Rb} 560,16 \mathrm{bn}$. Of these, 206,106 housing mortgage credits (HMC) in the amount of $\mathrm{Rb} 325,43 \mathrm{bn}$ were issued in Q2 2013. The total number of housing mortgage credits allotted in the first half-year of 2013 was 336,043, their total volume - Rb 542.50bn; of these, in Q2 2013, a total of 193,639 credits in the amount of $\mathrm{Rb} 315.51 \mathrm{bn}$ were allotted. The volume of housing mortgage credits allotted in Q2 2013 was $26.63 \%$ above the same index for the period of Q2 2012 , whereas the volume of housing mortgage credits issued in Q2 2012 had risen by 48.16\% on Q2 2011. In terms of credit value, the share of HMC denominated in foreign currencies and issued over the first half year of 2013 in the total volume of allotted HMC was $1.37 \%$ against $1.48 \%$ in the first half year of 2012 . The sum of residual debt against housing mortgage credits as of 1 July 2013 amounted to Rb 2.27 trillion, including $\mathrm{Rb} 2.15$ trillion against ruble-denominated credits (Fig. 1). At the same time, the share of debt outstanding against $\mathrm{HMC}$ denominated in foreign currencies was $5.31 \%$, or by $3.47 \mathrm{pp}$. lower than the same index registered as of 1 July 2012.

As of 1 July 2013, according to the RF CB, a total of 714 credit institutions were operating on the primary market, of which 665 credit institutions were issuing HMC, while 129 credit institutions were attracting refinancing in the secondary housing mortgage market. As of 1 July 2012, HC were issued by 723 credit institutions, HMC - by 660 credit institutions, while refinancing in the secondary market was attracted by 149 credit institutions.

According to data published by the RF $C B$, the amount of debt outstanding against HMC as of $1 \mathrm{Ju}$ ly 2013 was $\mathrm{Rb}$ 41.79bn ( $\mathrm{Rb} 26.75$ bn against ruble-

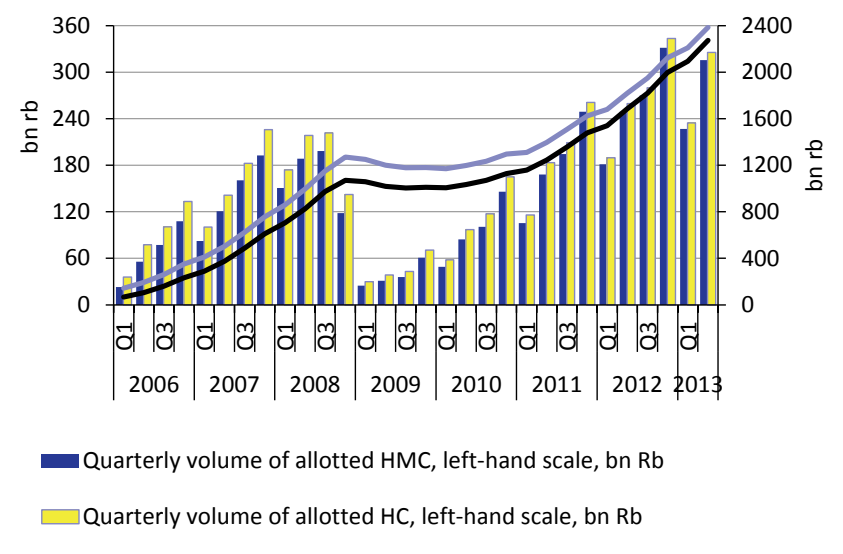

-Debt against allotted $\mathrm{HMC}$ as of end of quarter, right-hand scale, bn Rb

Debt against allotted $\mathrm{HC}$ as of end of quarter, right-hand scale, bn Rb

Source: data released by the RF Central Bank.

Fig. 1. Dynamics of Allotted Housing Mortgage Credits

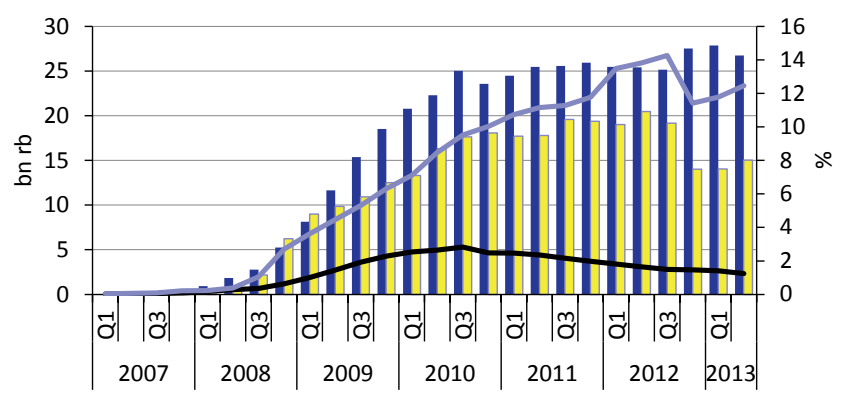

Outstanding debt against ruble-denominated credits, bn Rb

$\square$ Outstanding debt against credits denominated in foreign currencies, bn Rb

—Outstanding debt, as \% of residual debt against ruble-denominated credits

- Outstanding debt, as \% of residual debt against credits denominated in foreign currencies

Source: data released by the RF Central Bank.

Fig. 2. Changes in Outstanding Debt Against Housing Mortgage Credits, As of End of Quarter 
denominated credits and $\mathrm{Rb} 15.04 \mathrm{bn}$ against credits denominated in foreign currencies). The sum of total outstanding debt against ruble-denominated credits as of 1 July 2013 was $4.01 \%$ less in money terms than that recorded as of 1 April 2013, while in terms of per cent share of residual debt (1.24\%) it dropped by 0.17 p.p. Over the same period, outstanding debt against HMC denominated in foreign currencies rose in money terms by $7.11 \%$, while in terms of per cent share of residual debt (12.45\%) it increased by 0.67 p.p. (Fig. 2).

According to data published by the RF CB, the total sum of debt against $\mathrm{HMC}$, less outstanding debt, as of 1 July 2013 had risen on the same index registered as of 1 July 2012 by Rb 596.75bn, and so amounted to $96.32 \%$ of the sum of total debt (Fig. 3). Over the same period, the sum of debt against HMC with payments in arrears for periods between 1 and 30 days increased by $11.1 \mathrm{bn}$ and amounted to $1.63 \%$ of total debt, and the sum of debt against defaulted HMC (i.e., credits with payments in arrears for over 180 days) dropped by $\mathrm{Rb} 25.45$ bn to $1.15 \%$ of total debt (Fig. 3).

As reported by the RF CB, in the first half-year of 2013, the average weighted interest rates on HMC denominated in rubles and issued over one month rose to its record high of $12.9 \%$ in March, and then declined $12.6 \%$ in June (Fig. 4). The average weighted interest rate on HMC issued since the year's beginning over the first half-year of 2013 amounted to $12.7 \%$.

As shown by the data released by the RF CB, over first half year the lowest average weighted interest rate on ruble-denominated HMC (12.2\%) was offered by credit institutions rated 21st to 50th by the size of their assets, while the highest interest rate (13.2\%) by small-sized credit institutions rated 501st to 956th on the same list; the average market interest rate was $12.7 \%$. The average weighted interest rate over first half year of 2013 on HMC denominated in foreign currencies and issued since the year's beginning amounted to $9.8 \%$ - similar to its value for the entire period of 2012.

As of 1 July 2013, the average weighted crediting period for HMC issued since the year's beginning declined, as compared to 1 April 2013 , by $1.05 \%$ to 14.88 years for ruble-denominated HMC, while for HMC denominated in foreign currencies it increased by $1.09 \%$ to 13.18 years.

The average by-region amount of ruble-denominated HMC issued in the first half-year of 2013 increased across the board on the same period of 2012. Similarly to the situation in the first half year of 2012, the lowest credit value ( $\mathrm{Rb} 1.182 \mathrm{~m}$ ) was recorded in the Volga Federal District, the highest (Rb 3.595m) - in the city of Moscow. The average weighted interest rates on HMC for the first half year as of 1 July increased on 1 July

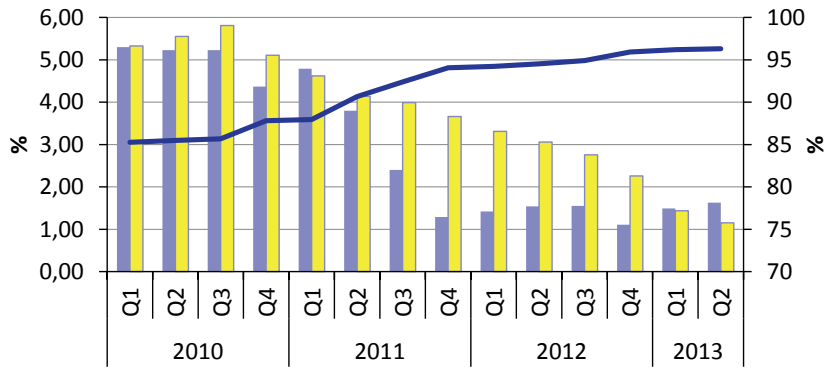

Debt against HMC with period of delay between 1 and 30 days, as \% of total debt, left-hand scale

$\square$ Debt against HMC with period of delay over 180 days, as \% of total debt, left-hand scale

- Debt against HMC without payment in arrears, as \% of total debt, righthand scale

Source: data released by the RF Central Bank.

Fig. 3. Debt Against Housing Mortgage Credits Broken by Period of Delay in Payment, As of End of Quarter

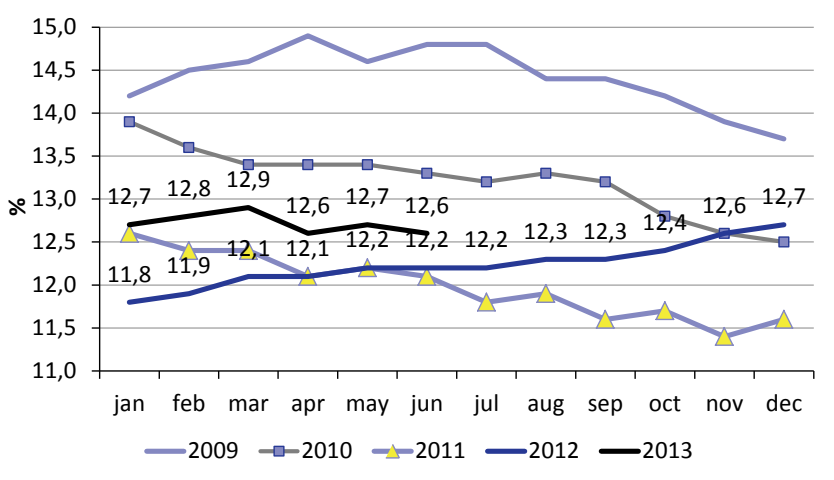

Source: data released by the RF Central Bank.

Fig. 4. Average Weighted Interest Rate on Rubledenominated HMC Allotted Over Month

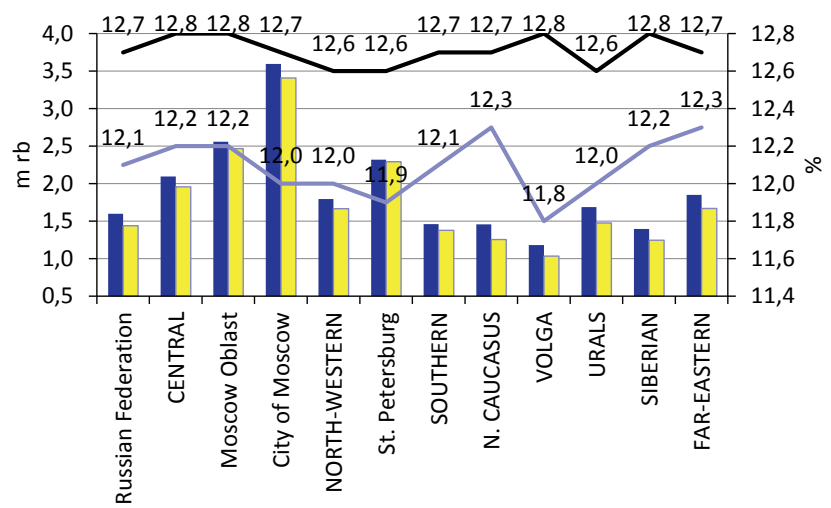

01.07.2013. 01.07.2013 Average credit amount, $\mathrm{m} \mathrm{Rb}$ $\square$ 01.07.2012. 01.07.2012 Average credit amount, $\mathrm{m} \mathrm{Rb}$ — 01.07.2013. 01.07.2013 Average weighted interest rate, \% -01.07.2012. 01.07.2012 Average weighted interest rate, \%

Source: data released by the RF Central Bank.

Fig. 5. Average Weighted Data on Housing Mortgage Credits Allotted Since Year's Beginning, by Region 
FEATURES OF HMS REFINANCED BY THE AHML IN JUNEE 2013, BY FEDERAL DISTRICT*

\begin{tabular}{|c|c|c|c|c|c|c|c|c|c|}
\hline & RF & CFD & NWFD & SFD & NCFD & VGD & UFD & SFD & FEFD \\
\hline $\begin{array}{l}\text { Average amount of } \\
\mathrm{HMC} \text {, thousand } \mathrm{Rb}\end{array}$ & 1,248 & 1,367 & 1,342 & 1,234 & 1,115 & 1,147 & 1,253 & 1,252 & 1,438 \\
\hline $\begin{array}{l}\text { Average weighted interest rate } \\
\text { on ruble-denominated HMC, } \%\end{array}$ & 11.61 & 11.79 & 11.26 & 12.15 & 12.82 & 11.66 & 11.89 & 11.04 & 12.04 \\
\hline $\begin{array}{l}\text { Average weighted crediting } \\
\text { period for HMC, years }\end{array}$ & 17.3 & 17.2 & 16 & 18.2 & 16.9 & 17.4 & 18.3 & 17.5 & 15.9 \\
\hline Average age of borrower, years & 34 & 36 & 36 & 33 & 35 & 34 & 33 & 34 & 34 \\
\hline $\begin{array}{l}\text { Average aggregate income of } \\
\text { borrower, thousand } \mathrm{Rb} \text { per month }\end{array}$ & 29.5 & 33.2 & 34.7 & 29.1 & 23.1 & 25.3 & 30.3 & 30.2 & 38.3 \\
\hline $\begin{array}{l}\text { Average size of purchased } \\
\text { dwelling, } m 2\end{array}$ & 49.1 & 49.6 & 50.4 & 56.7 & 54 & 47.8 & 48.8 & 48.9 & 45.5 \\
\hline $\begin{array}{l}\text { Average price of dwelling } \\
\text { purchased on mortgage, } \mathrm{Rb} / \mathrm{m} 2\end{array}$ & 45,289 & 51,454 & 52,509 & 39,713 & 32,773 & 41,999 & 43,379 & 42,398 & 60,597 \\
\hline
\end{tabular}

* Data for products Standard, Novostroika [New Construction Projects], Young Teachers - Standard.

Source: data released by the Agency for Housing Mortgage Lending.

2012 all federal districts and regions, rising to the record high value of $12.8 \%$ in some of them (Fig. 5).

Over the first half year of 2013, the average weighted interest rate on ruble-denominated $\mathrm{HMC}$ refinanced by the Agency for Housing Mortgage Lending (AHML) across the Russian Federation (products Standard, Novostroika [New Construction Projects], Young Teachers - Standard, Young Scientists and Military Housing Mortgage was $11.35 \%$, the average weighted crediting period -14.5 years. Over the same period of 2012, the average weighted interest rate on standard products and on Military Housing Mortgage was $10.5 \%$, the average weighted crediting period for standard products -16.5 years. The average weighted interest rate on the AHML's credits for June 2013 amounted to $11.61 \%$, while the average age of borrowers was 34 years, their average aggregate income - Rb 29.5 thousand per month (Table 1). The lowest interest rate was registered in the Siberian Federal District (SFD) $11.04 \%$, the lowest price per square meter of dwelling ( $\mathrm{Rb} 32,773$ ) - in the North Caucasus Federal District. The average initial installment size across the Russian Federation was $40.5 \%$ of the mortgage value.

Over the first half year of 2013, the AHML refinanced 15,591 credits in the amount of $\mathrm{Rb} 22.3 \mathrm{bn}$, which is less by $22.07 \%$ in quantitative terms and by $14.37 \%$ in terms of value than the parameters for the corresponding period of 2012 . The volume of mortgages bought out by the AHML amounted to $4.4 \%$ of the total housing mortgage market volume. In 2013, the Agency bought out mortgage bonds held by market participants to the total value of $\mathrm{Rb} 10.71 \mathrm{bn}$ and concluded contracts for buying out older mortgage bonds to the value of $\mathrm{Rb} 32.68 \mathrm{bn}$ with maturity dates between 1 November 2013 through 31 December 2014. At present, the AHML is elaborating interaction schemes for the interbank market and a set of model documents for banks' mutual credits secured by housing mortgages. Such schemes are designed to enable banks - issuers of housing mortgage credits to attract interbank credits in order to cover their expenditures on issued housing mortgage loans, to increase the volume of their housing mortgage lending, and to accumulate a sufficient volume of liabilities for issuing mortgage-backed securities. It is expected that under this scheme the AHML will be able to guarantee mortgage buyouts in cases when mortgage banks are unable to repay loans to creditor banks.

From 1 August 2013, the Agency introduced a special deduction from interest rates under its housing mortgage programs in the amount of $0.5 \mathrm{pp}$. for the staff of those companies that have envisaged special financial support of their employees participating in housing acquisition or housing construction projects.

The results of sociological survey conducted in the spring of 2013 by the AHML in conjunction with the Institute for Market Research - GfK Rus demonstrate that the number of citizens who consider themselves to be potential borrowers under housing mortgage lending programs increased over the half-year period by 5 p.p. to $24 \%$ ( $13.1 \mathrm{~m}$ households), and that $6 \%$ of citizens, if they should need to buy a dwelling, will certainly take out a housing mortgage. 